DOI: $10.19195 / 2084-5065.46 .3$

\title{
Targnięcie się pokrzywdzonego na własne życie jako typ kwalifikowany przestępstwa stalkingu
}

\author{
ANNA MusZYŃSKA \\ Katedra Prawa Karnego Materialnego \\ Wydział Prawa, Administracji i Ekonomii Uniwersytetu Wrocławskiego \\ ANNA JASKÓŁA \\ Katedra Prawa Karnego Materialnego \\ Wydział Prawa, Administracji i Ekonomii Uniwersytetu Wrocławskiego
}

\section{Wprowadzenie}

Podejmując problematykę stalkingu, należy zauważyć, że polskie ustawodawstwo karne przez długi okres nie przewidywało odrębnego przestępstwa określanego mianem stalkingu1. Zasadne wydaje się zatem

1 Termin „stalking” wywodzi się z żargonu myśliwskiego, sposób działania sprawcy czynu zabronionego uporczywie nękającego ofiarę jest bowiem tożsamy z zachowaniem osoby trudniącej się łowiectwem (J. Skarżyńska-Sernegalia, Stalking: od miłości do zbrodni - nowe wyzwanie dla psychologii, kryminologii i zespołów interdyscyplinarnych przeciwdziałajacych przemocy, [w:] E. Szafrańska, A. Szołtek, Psychologia na rzecz bezpieczeństwa publicznego, Szczytno 2009, s. 75). Zgodnie z definicją zawartą w Longman Dictionary of Contemporary English termin „stalk” tłumaczy się jako: polować, podążać za, śledzić w celu zabicia zarówno zwierzęcia, jak i człowieka. Niemniej jednak sprawcą stalkingu — „stalkerem” — może być wyłącznie osoba, która przez pewien czas podąża za ofiarą z zamiarem dokonania gwałtu lub zabójstwa (Longman Dictionary of Contemporary English, England 1995, s. 1399).

Nowa Kodyfikacja Prawa Karnego 46, 2017

(C) for this edition by CNS 
stwierdzenie, że zachowania sprawcy bezprawnie ingerującego w sferę prywatności oraz godzącego w bezpieczeństwo pokrzywdzonego pozostawały bezkarne, gdyż organy ścigania nie dysponowały odpowiednimi środkami reakcji prawnokarnej, pozwalającymi na zapewnienie ofiarom efektywnej ochrony ${ }^{2}$. Wspomnieć także należy, iż odpowiedzialność karna stalkera była kwalifikowana z innych przepisów karnych, jedynie częściowo oddających istotę tego zjawiska. Penalizacja zachowań sprawcy stalkingu była możliwa w oparciu o pewne quasi-rozwiązania, jak np. art. 107 ustawy z dnia 20 maja 1971 r. - Kodeks wykroczeń ${ }^{3}$, typizujący wykroczenie złośliwego niepokojenia drugiego człowieka, czy art. 207 ustawy z dnia 6 czerwca 1997 r. - Kodeks karny ${ }^{4}$, sankcjonujący przestępstwo znęcania się ${ }^{5}$. Zmiany wprowadziła dopiero nowelizacja kodeksu karnego, dokonana przez prawodawcę ustawą z dnia 25 lutego $2011 \mathrm{r}$. o zmianie ustawy - Kodeks karny ${ }^{6}$ poprzez dodanie nowego czynu karalnego, stypizowanego w art. 190a k.k. jako: występek uporczywego nękania innej osoby lub osoby jej najbliższej prowadzący do wzbudzenia tym samym uzasadnionego okolicznościami poczucia zagrożenia lub istotnego naruszenia prywatności (§ 1), występek przywłaszczenia tożsamości ofiary ( $(2)$ oraz typ kwalifikowany przez następstwo, tj. występek targnięcia się pokrzywdzonego na własne życie (§ 3).

Przypominając dane statystyczne zaprezentowane przez Wydział Statystyki i Analiz Wymiaru Sprawiedliwości, ukazujące zjawisko stalkingu w ujęciu ogólnokrajowym, a odnoszące się do osób prawomocnie skazanych w 2011 r., według rodzajów przestępstw przez nich popełnionych oraz wymiaru kary, należy stwierdzić, że najczęściej dochodziło do skazań za występek uporczywego nękania z art. 190a § 1 k.k. Dokładnie rzecz ujmując, skazań tych w 2011 r. było 38. Liczba ta wydaje się niewielka, jeśli nie zwróci się uwagi na łączną liczbę skazań z art. 190a k.k.,

${ }^{2}$ Kodeks karny. Część szczególna. Tom I. Komentarz art. 117-221, red. M. Królikowski, R. Zawłocki, Warszawa 2013, s. 538.

3 Dz.U. z 1991, Nr 12, poz. 114 ze zm.

4 T.j. Dz.U. z 2016, poz. 1137 ze zm.

5 Kodeks karny. Komentarz, red. A. Grześkowiak, K. Wiak, wyd. 2, Warszawa 2014, s. 739; Kodeks karny. Część szczegółowa. Tom II. Komentarz do art. 117-277 k.k., red. A. Zoll, wyd. 4, Warszawa 2013, s. 605.

6 Dz.U. z 2011 r., Nr 72, poz. 381.

Nowa Kodyfikacja Prawa Karnego 46, 2017

(C) for this edition by CNS 
obejmującą 43 przypadki. W dalszej kolejności pojawiał się występek przywłaszczenia tożsamości ofiary stypizowany w art. 190a $\S 2$ k.k. (4 skazania), a najrzadziej dochodziło do skazania za występek targnięcia się pokrzywdzonego na własne życie $\mathrm{z}$ art. 190a $§ 3$ k.k. (odnotowano wówczas zaledwie 1 przypadek) ${ }^{7}$. W kolejnych latach z art. 190a $§ 3$ k.k. odnotowano odpowiednio w $2012-1,2013-1,2014-3,2015-$ 1 skazanie $^{8}$.

W świetle powyższych danych należy stwierdzić, że choć przypadki skazań za przestępstwo z art. 190a $\S 3 \mathrm{k} . \mathrm{k}$. należą do rzadkości, to istnieje potrzeba ich kryminalizacji w celu zapewnienia jak najpełniejszej ochrony osobom pokrzywdzonym. $Z$ tych względów warto poddać analizie znamiona przestępstwa targnięcia się pokrzywdzonego na własne życie jako typu kwalifikowanego przestępstwa stalkingu zdefiniowanego w art. 190a $\S 1$ k.k. Występku tego nie sposób jednak rozważać w oderwaniu od art. 190a $\S 1$ k.k. penalizującego stalking w typie podstawowym, tym bardziej że sam prawodawca w treści przepisu $\S 3$ art. 190a k.k. wprowadza odesłanie do czynu określonego w $§ 1$.

\section{Kwestia dobra prawnie chronionego} oraz podmiotu występku z art. 190a $\S 3$ k.k.

Prawodawca usytuował stalking w rozdziale XXIII kodeksu karnego, który poświęcono przestępstwom przeciwko wolności. A zatem należy przyjąć, iż dobro prawnie chronione na gruncie art. 190a $§ 1$ k.k. to szeroko rozumiana wolność. Źródłem owej wolności — zgodnie z art. 30 Konstytucji Rzeczypospolitej Polskiej z dnia 2 kwietnia 1997 r. ${ }^{9}$ — jest przyrodzona i niezbywalna godność jednostki, która pozostaje nienaruszalna, jej poszanowanie i ochrona należą zaś do zadań władzy publicznej. Wspomnieć także należy, iż art. 31 ust. 1-2 przywołanego aktu norma-

7 Prawomocnie skazani dorośli wg rodzajów przestępstwi wymiaru kary w 2011 r. — czyn główny, http://bip.ms.gov.pl/pl/dzialalnosc/statystyki/statystyki-2013/ (dostęp: 25 kwietnia 2016).

8 Skazania prawomocne, wyroki za stalking w Polsce w latach 2011-2015, https:// stalking.com.pl/2016/08/17/wyroki-za-uporczywe-nekanie-statystyka-skazan-za-lata-2011-2015/ (dostęp: 9 lipca 2017).

9 Dz.U. z 1997 r., Nr 78, poz. 483 ze zm.

Nowa Kodyfikacja Prawa Karnego 46, 2017

(C) for this edition by CNS 
tywnego stanowi gwarancję ochrony prawnej tejże wolności, jak również nakłada na każdego człowieka obowiązek jej poszanowania ${ }^{10}$.

Owa wolność występuje w dwóch podstawowych wariantach, tj. jako wolność „od czegoś” oraz wolność „do czegoś”. W pierwszym ujęciu ochroną objęto dobrostan psychiczny jednostki przed jakimikolwiek zamachami powodującymi jej dyskomfort, m.in. poprzez wzbudzenie stanu zagrożenia. W drugim zaś wariancie chodzi o konstytucyjne prawo do prywatności przysługujące każdemu, co wynika expressis verbis z treści art. 47 ustawy zasadniczej ${ }^{11}$. Jednocześnie zaznaczyć należy, że chociaż przedmiot ochrony na gruncie art. 190a $\S 3$ k.k. jest tożsamy, jak w przypadku czynu zabronionego stypizowanego w art. 190a $\S 1$ k.k., to w odniesieniu do występku targnięcia się pokrzywdzonego na własne życie pojawia się dodatkowe dobro prawnie chronione, określane zgodnie przez doktrynę prawa karnego jako życie człowieka ${ }^{12}$.

Zdefiniowanie podmiotu przestępstwa stalkingu, zarówno w typie podstawowym, jak i w typie kwalifikowanym przez następstwo, nie wzbudza najmniejszych wątpliwości interpretacyjnych. Ustawodawca bowiem w art. $190 \S 1$ k.k. posługuje się zaimkiem „kto”, w treści art. 190a $\S 3$ k.k. stanowi zaś: ,jeśli następstwem czynu określonego w $\S 1$ [...] jest targnięcie się pokrzywdzonego na własne życie”. Konstrukcja omawianej normy prawnej przesądza zatem o przyjęciu przez prawodawcę, że sprawcą obu występków może być każdy człowiek, o ile jest zdolny do ponoszenia odpowiedzialności karnej na kanwie kodeksu karnego. Należy wyraźnie przy tym podkreślić, iż stalker nie musi posiadać żadnych dodatkowych i szczególnych kwalifikacji. Taka regulacja pozwala stwierdzić, że zarówno występek uporczywego nękania innej osoby, jak i występek targnięcia się pokrzywdzonego na własne życie należą do kategorii przestępstw powszechnych z uwagi na ogólnosprawczy charakter ${ }^{13}$.

10 Konstytucja Rzeczypospolitej Polskiej z dnia 2 kwietnia 1997 r. (Dz.U. z 1997 r., Nr 78, poz. 483 ze zm.) (dalej jako: Konstytucja RP).

11 Konstytucja RP; Kodeks karny. Komentarz, red. M. Filar, wyd. 4, Warszawa 2014, s. 1104; R. Krajewski, Przestępstwo nękania innej osoby lub podszywania się pod nią, ,Przegląd Sądowy” 2012, nr 5, s. 24.

12 Np. Kodeks karny. Komentarz, red. T. Bojarski, wyd. 7, Warszawa 2016, s. 532.

13 Kodeks karny. Komentarz, red. R.A. Stefański, wyd. 2, Warszawa 2015, s. 1092; Kodeks karny. Część szczegółowa. Tom II. Komentarz do art. 117-277..., s. 606.

Nowa Kodyfikacja Prawa Karnego 46, 2017

(C) for this edition by CNS 


\section{Targnięcie się pokrzywdzonego na własne życie jako następstwo uporczywego nękania ofiary}

Zachowanie sprawcy stalkingu, uporczywie nękającego swoją ofiarę, może wiązać się z dużym obciążeniem psychicznym, w rezultacie czego pokrzywdzony podejmie decyzję o targnięciu się na własne życie. Odpowiedzialność karna stalkera będzie wówczas kwalifikowana $\mathrm{z}$ art. 190a $\S 3$ k.k., przepis ten stanowi bowiem lex specialis względem art. 190a $\S 1$ k.k. Niemniej jednak, aby móc przypisać sprawcy znamiona czynu zabronionego stypizowanego $\mathrm{w}$ art. 190a $§ 3$ k.k., niezbędne jest przede wszystkim wykazanie istnienia związku przyczynowego pomiędzy uporczywym nękaniem innej osoby lub osoby jej najbliższej (zgodnie $\mathrm{z}$ definicją legalną $\mathrm{z}$ art. $115 \S 11$ k.k.), prowadzącym do wzbudzenia w niej uzasadnionego okolicznościami poczucia zagrożenia lub istotnego naruszenia prywatności, a zamachem na własne życie. Dlatego też w celu zrozumienia istoty występku kwalifikowanego przez następstwo zasadne jest odniesienie do znamion strony przedmiotowej czynu zabronionego w typie podstawowym.

Czynność sprawcza występku z art. 190a $§ 1$ k.k. została określona przez prawodawcę za pomocą znamienia czasownikowego „nęka”. Niestety na gruncie obowiązującej ustawy karnej brakuje definicji legalnej tegoż terminu, co powoduje pewne trudności interpretacyjne. Wyjaśnienia w przedmiocie rozumienia przywołanego wyżej terminu można poszukiwać w słowniku języka polskiego, który definiuje nękanie jako: ustawiczne dręczenie, trapienie, niepokojenie innej osoby, dokuczanie, niedawanie ani chwili spokoju ${ }^{14}$. Niewątpliwie z brzmienia czasownikowego expressis verbis wynika, że zachowanie stalkera powinno cechować się powtarzalnością oraz wielokrotnością. Stąd też należy przyjąć, iż stalking w typie podstawowym jest przestępstwem nie jedno-, lecz wieloczynowym, przy czym warunkiem koniecznym jest odbiór tychże zachowań przez ofiarę. Działania muszą być podjęte przez sprawcę wbrew woli ofiary. Pokrzywdzony winien wyraźnie zakomunikować stalkerowi, że jego działania są wysoce niepożądane $\mathrm{i}$ - w związku z tym — ofiara

14 Stownik języka polskiego PWN, http://sjp.pwn.pl/doroszewski/nekac;5457258. html (dostęp: 26 kwietnia 2016).

Nowa Kodyfikacja Prawa Karnego 46, 2017

(C) for this edition by CNS 
nie wyraża zgody na ich kontynuację $e^{15}$. Polski kodeks karny, w przeciwieństwie np. do regulacji stalkingu w prawie japońskim ${ }^{16}$, nie precyzuje katalogu tychże zachowań. Formy nękania nierzadko są niejednorodne i de facto każdorazowo uzależnione od pomysłowości danego sprawcy. Wśród przykładów można wymienić m.in. wysyłanie krótkich wiadomości tekstowych (SMS), wykonywanie połączeń telefonicznych, wysyłanie korespondencji za pośrednictwem poczty elektronicznej lub poczty tradycyjnej, nachodzenie w miejscu zamieszkania lub w miejscu zatrudnienia, śledzenie ofiary itp. Podkreślenia wymaga okoliczność, iż wszystkie te czynności muszą mieć charakter wielokrotny ${ }^{17}$.

Należy także zauważyć, iż na mocy art. 190a $§ 1$ k.k. prawodawca penalizuje wyłącznie nękanie cechujące się uporczywością. Po raz kolejny polski ustawodawca posługuje się zwrotem niedookreślonym, który stanowi również znamię innych przestępstw, tj. stypizowanych w art. 145 $\S 1$ pkt 1 k.k., art. $209 \S 1$ k.k., art. $219 \S 1$ la k.k., art. $341 \S 2$ k.k. ${ }^{18}$ Termin „uporczywość” został objaśniony przez judykaturę, w tym w szczególności przez orzecznictwo Sądu Najwyższego. W tym miejscu warto zwrócić uwagę na wytyczne wymiaru sprawiedliwości i praktyki sądowej w zakresie prawnokarnej ochrony rodziny z dnia 9 czerwca 1976 r., w których Sąd Najwyższy stwierdził, że w skład uporczywości wchodzą elementy subiektywno-obiektywne. Element subiektywny wiąże się z nastawieniem psychicznym sprawcy i znajduje wyraz „w nieustępliwości, chęci postawienia na swoim (obojętnie z jakich pobudek), podtrzymaniu własnego stanowiska na przekór ewentualnym próbom jego zmiany"19. Natomiast drugi element składowy oznacza trwałość takiego stanu przez pewien dłuższy okres. Chociaż uchwała z 1976 r. wyraża stanowisko sprzed zmiany ustawodawstwa karnego i odnosi się do występku nieali-

15 R. Krajewski, op. cit., s. 24; Kodeks karny. Komentarz, red. A. Grześkowiak, K. Wiak..., s. 739; Kodeks karny. Część szczególna. Tom I. Komentarz art. 117-221..., S. 514.

16 Por. D.E. Chapman, B.H. Spitzberg, Are you following me? A study of unwanted relationship pursuit and stalking in Japan: What behaviors are prevalant?, „Bulletin of Hijiyama University" 2003, nr 10, s. 94.

17 Kodeks karny. Część szczegółowa. Tom II. Komentarz do art. 117-277..., s. 606.

18 Kodeks karny. Część szczególna. Tom I. Komentarz art. 117-221..., s. 541.

19 Wytyczne wymiaru sprawiedliwości i praktyki sądowej w zakresie prawnokarnej ochrony rodziny z dnia 9 czerwca 1976 r., VI KZP 13/75.

Nowa Kodyfikacja Prawa Karnego 46, 2017

(C) for this edition by CNS 
mentacji, to ów pogląd zachowuje swoją aktualność w świetle obowiązującego stanu prawnego. Stąd też zasadne wydaje się interpretowanie terminu „uporczywość”, należącego do znamion stalkingu, w ten sam sposób, co wyżej przywołany ${ }^{20}$.

Stalking w typie podstawowym jest przestępstwem niewątpliwie materialnym, albowiem konieczne do realizacji znamion czynu zabronionego $\mathrm{z}$ art. 190a $\S 1$ k.k. jest zaistnienie skutku — w jednej bądź w obu postaciach — tj. wzbudzenia w ofierze uzasadnionego okolicznościami poczucia zagrożenia lub istotnego naruszenia jej prywatności. Równoczesne wystąpienie obu następstw jest dopuszczalne z uwagi na zastosowaną przez prawodawcę konstrukcję, gdyż w treści tego przepisu prawnego wykorzystano spójnik „lub”, oznaczający alternatywę łączną21. Ocena istnienia poczucia zagrożenia winna być dokonywana z uwzględnieniem obiektywnych kryteriów — wzorca przeciętnego obywatela. Jeśli zaś chodzi o drugi skutek, to ustawodawca wprost stanowi, że jedynie istotne naruszenie prywatności jest penalizowane na mocy art. 190a $\S 1$ k.k. $\mathrm{Na}$ gruncie omawianego przepisu prawnego prawodawca posługuje się tzw. superfluum ustawowym, gdyż prywatność należy do dóbr na tyle ważnych, że każde jej naruszenie powinno być uznawane za istotne ${ }^{22}$.

Odnosząc się z kolei do strony przedmiotowej typu kwalifikowanego przestępstwa stalkingu, stwierdzić należy, iż odpowiada ona w istocie czynnościom sprawczym określonym w art. 190a § 1 k.k. Dodatkowa okoliczność, pojawiająca się na gruncie art. 190a § 3 k.k. i przesądzająca o surowszych granicach ustawowego zagrożenia karą, to następstwo przestępnego działania sprawcy w postaci targnięcia się pokrzywdzonego na własne życie. Podobnie jak termin „nękać” czy „uporczywość”, zwrot „targnięcie się na własne życie” nie posiada definicji legalnej. Przy czym wskazać należy, że owo określenie należy również do znamion innych przestępstw kodeksowych, tj. art. 151 k.k., art. $207 \S 3$ k.k. czy art. 352 $\S 3$ k.k. W znaczeniu słownikowym ,targnięcie się na własne życie” jest

20 J. Chamernik, Przestępstwo stalkingu w regulacji kodeksu karnego, „Zeszyty Naukowe Uniwersytetu Przyrodniczo-Humanistycznego w Siedlcach. Seria: Administracja i Zarządzanie" 2013, nr 99, s. 309-310.

21 Kodeks karny. Część szczegółowa. Tom II. Komentarz do art. 117-277..., s. 608.

22 Kodeks karny. Część szczególna. Komentarz. Art.190 a, red. J. Giezek, stan prawny: 1 marca 2014, Lex.

Nowa Kodyfikacja Prawa Karnego 46, 2017

(C) for this edition by CNS 
najczęściej traktowane jako synonim popełnienia samobójstwa bądź zamachu samobójczego, które to określenia wiążą się z odebraniem sobie życia przez człowieka ${ }^{23}$.

Czyn zabroniony stypizowany w art. 190a $§ 3$ k.k. należy także do kategorii przestępstw materialnych. Niemniej jednak, do przyjęcia kwalifikacji prawnej z tego przepisu nie ma znaczenia, czy owo targnięcie się pokrzywdzonego na własne życie skutkowało śmiercią. A zatem stalker zostanie pociągnięty do odpowiedzialności karnej już w przypadku zamachu samobójczego usiłowanego. Stąd też konieczne jest wykazanie istnienia związku przyczynowego pomiędzy przestępnym działaniem sprawcy uporczywie nękającego ofiarę a następstwem takiego zachowania, tj. targnięciem się na własne życie. W toku prowadzonego postępowania karnego obrona nierzadko będzie podejmowała próby zmierzające do udowodnienia, iż na decyzję ofiary nałożyły się inne, równolegle występujące okoliczności ${ }^{24}$.

\section{Wybrane aspekty strony podmiotowej}

Strona podmiotowa występku z art. 190a $§ 1$ k.k. polega na umyślności. Biorąc pod uwagę znamię modalne w postaci uporczywości, zasadne wydaje się stwierdzenie, że stalker działa z zamiarem wyłącznie bezpośrednim. Uwzględniając z kolei dopuszczalne postacie skutku, tj. wzbudzenie w pokrzywdzonym uzasadnionego okolicznościami poczucia zagrożenia lub istotne naruszenie prywatności, przyjąć należy, iż możliwe jest objęcie ich zarówno zamiarem bezpośrednim, jak i ewentualnym ${ }^{25}$.

Nawiązując do przestępstwa kwalifikowanego przez następstwo, należy stwierdzić, że strona podmiotowa tego czynu zabronionego ma charakter mieszany. Ustawodawca bowiem na gruncie art. 190a $§ 3$ k.k. posłużył się dość ciekawą konstrukcją tzw. winy kombinowanej w wariancie klasycznym, tj. umyślno-nieumyślnym. Wariant ten zakłada popełnienie przez sprawcę czynu zabronionego umyślnie, w zamiarze bezpośrednim

23 K. Burdziak, Przedmiot czynności wykonawczej przestępstwa z art. 151 kodeksu karnego, „Zeszyty Naukowe Uniwersytetu Szczecińskiego” 2015, nr 861, s. 21-24.

24 Kodeks karny. Komentarz, red. A. Grześkowiak, K. Wiak..., s. 741; Kodeks karny. Komentarz, red. R.A. Stefański..., s. 1307-1308.

25 Kodeks karny. Część szczególna. Komentarz. Art. 190 a...

Nowa Kodyfikacja Prawa Karnego 46, 2017

(C) for this edition by CNS 
lub ewentualnym. Jeśli zaś chodzi o wynikające z niego następstwo, to sprawca ,nie chce, nie godzi się na nie, ale je przewiduje, sądząc, że go uniknie, lub nie przewiduje, choć mógł je przewidzieć" 26 .

Odnosząc powyższy schemat do stalkingu, sprawcy można postawić zarzut popełnienia czynu zabronionego objętego umyślnością co do typu podstawowego, czyli w omawianym przypadku dotyczy to występku uporczywego nękania stypizowanego w art. 190a $\S 1$ k.k., a w nawiązaniu do następstwa w postaci targnięcia się pokrzywdzonego na własne życie ów skutek objęty będzie jedynie nieumyślnością, o ile sprawca go przewidywał albo mógł przewidzieć, co wynika z treści art. 9 § 3 k.k. ${ }^{27}$

\section{Tryb ścigania i kilka uwag o sankcji karnej}

Analizując występek targnięcia się pokrzywdzonego na własne życie, należy także zwrócić uwagę na kwestie dotyczące zarówno trybu ścigania, jak i sankcji karnej przewidzianej za to przestępstwo.

Tryb ścigania został unormowany w art. 190a $§ 4$ k.k. Zgodnie z treścią przywołanego przepisu prawnego ściganie przestępstw stypizowanych w art. 190a § 1-2 k.k., tj. występku uporczywego nękania oraz występku przywłaszczenia tożsamości ofiary, następuje na wniosek pokrzywdzonego. Złożenie wniosku warunkuje wszczęcie postępowania karnego, które odtąd toczy się już z urzędu ${ }^{28}$. Jednocześnie wskazać należy, iż na gruncie art. 190a $\S 4$ k.k. ustawodawca całkowicie pomija tryb ścigania przestępstwa kwalifikowanego przez następstwo. Dlatego też, aby znaleźć uzasadnienie dla zastosowanego zabiegu legislacyjnego, należy odwołać się do ustawy z dnia 6 czerwca 1997 r. - Kodeks postępowania karnego ${ }^{29}$, w tym w szczególności do art. 9 § 1 k.p.k. Przywołany przepis prawny wprowadza tzw. zasadę ścigania z urzędu, która zakłada prowadzenie postępowania i dokonywanie czynności przez organy pro-

26 A. Opar, Wina kombinowana w prawie karnym jako dualizm form winy, ,Studia Prawnoustrojowe" 2015, nr 2007, s. 197.

27 Kodeks karny. Komentarz, red. A. Grześkowiak, K. Wiak..., s. 89; A. Opar, op. cit., s. 197.

28 K. Marszał, Proces karny. Zagadnienia ogólne, wyd. 2, Katowice 2013, s. 88.

29 Ustawa z dnia 6 czerwca 1997 r. — Kodeks postępowania karnego (Dz.U. z 2016, poz. 1749 z późn. zm.) (dalej jako: k.p.k.).

Nowa Kodyfikacja Prawa Karnego 46, 2017

(C) for this edition by CNS 
cesowe z własnej inicjatywy. Wyjątkowo, tj. w przypadkach wskazanych w ustawie, niektóre czyny zabronione są ścigane na wniosek (tak jak przykładowo dotyczy to występków z art. 190a § 1-2 k.k.) lub z oskarżenia prywatnego ${ }^{30}$. A zatem a contrario przyjąć należy, iż w pozostałym zakresie — w tym obejmującym występek targnięcia się pokrzywdzonego na własne życie - właściwy tryb to ściganie przestępstw z urzędu ${ }^{31}$. Zdaniem M. Mozgawy to zróżnicowanie jest podyktowane większą wartością dobra prawnie chronionego na mocy art. 190a $§ 3$ k.k., jakim jest życie człowieka, od tego, które stanowi przedmiot ochrony w odniesieniu do typu podstawowego przestępstwa stalkingu ${ }^{32}$.

Kolejne zagadnienie, którego z uwagi na dość kontrowersyjne i nie do końca zrozumiałe uregulowanie nie sposób pominąć, dotyczy zakresu ustawowych granic zagrożenia karą pozbawienia wolności. Sankcja karna, grożąca sprawcy za występek uporczywego nękania lub występek przywłaszczenia tożsamości ofiary, została unormowana w sposób jednolity. Ustawodawca bowiem wskazuje, iż w powyższych przypadkach sprawca podlega karze pozbawienia wolności do lat 3. W nawiązaniu do zachowań stalkera prowadzących w rezultacie do targnięcia się pokrzywdzonego na własne życie ustawodawca przewiduje surowszą odpowiedzialność karną w postaci kary pozbawienia wolności od 1 roku do lat 10.

Należy podkreślić, iż typ kwalifikowany przez następstwo występuje także w przypadku innych przestępstw, tj. znęcania stypizowanego w art. 207 k.k. oraz w art. 352 k.k. Sankcją karną grożącą za te czyny jest kara pozbawienia wolności od 2 do 12 lat. Słuszna zatem wydaje się być argumentacja, prezentowana przez niektórych przedstawicieli doktryny prawa karnego, w tym m.in. M. Mozgawę, który zwraca uwagę na istnienie pewnej dysharmonii. Trudno bowiem dopatrzyć się różnicy o charakterze jakościowym pomiędzy targnięciem się pokrzywdzonego na własne życie pozostającym w związku przyczynowym z zachowaniem

30 A. Murzynowski, Istota i zasady procesu karnego, wyd. 3, Warszawa 1994, s. 143.

31 Wykład prawa karnego procesowego, red. P. Kruszewski, wyd. 2, Białystok 1998, s. 32.

32 Kodeks karny. Komentarz, red. M. Mozgawa, Warszawa 2013, s. 433-434.

Nowa Kodyfikacja Prawa Karnego 46, 2017

(C) for this edition by CNS 
sprawcy znęcania, opisanym w treści art. 207 k.k. czy 352 k.k., i zachowaniem stalkera uporczywie nękającego swoją ofiarę 33 .

Mając na względzie koncepcję racjonalnego prawodawcy, można próbować bronić zastosowanego na gruncie przywołanych przepisów prawnych zabiegu legislacyjnego, choć takie argumenty niekoniecznie muszą być uznane za trafne. W pierwszej kolejności należy wskazać, że czynność sprawcza przestępstw stypizowanych w art. 207 k.k. oraz 352 k.k. została ujęta dość szeroko, gdyż obejmuje nie tylko znęcanie psychiczne, ale i fizyczne. Natomiast stalking jest określany w literaturze przedmiotu jako noszący znamiona przemocy emocjonalnej. Ponadto, prawodawca w sposób precyzyjny definiuje krąg podmiotów korzystających z ochrony prawnokarnej na mocy art. 207 k.k., do których zalicza osoby najbliższe, inne osoby pozostające $\mathrm{w}$ stosunku stałym lub przemijającym, małoletnich, jak również osoby nieporadne psychicznie lub fizycznie. $Z$ kolei $\mathrm{z}$ treści art. $352 \mathrm{k}$.k. wprost wynika, że pomiędzy sprawcą a ofiarą także występują pewne szczególne powiązania, gdyż podmioty te pozostają w relacji żołnierz-podwładny ${ }^{34}$. Ustawodawca w artykule 190a § 1 k.k. ujmuje przedmiot czynności wykonawczej w sposób lapidarny, pozostawiając poza obszarem zainteresowań rodzaj relacji łączących stalkera z pokrzywdzonym. Należy też zauważyć, że nierzadko sprawcą stalkingu są osoby nie tylko należące do grona bliskich bądź dalszych znajomych, ale i zupełnie nieznane ofierze ${ }^{35}$.

\section{Podsumowanie}

Zamykając powyższe rozważania, należy podkreślić, iż problematyka dotycząca stalkingu stanowi istotne zagadnienie normatywne, funkcjonujące w obrocie prawnym od dnia 6 czerwca 2011 r. Ustawodawca, chcąc zapewnić ofiarom jak najpełniejszą ochronę prawnokarną, w treści art. 190a $\S 3$ k.k. wprowadził tzw. typ kwalifikowany przez następstwo w postaci targnięcia się pokrzywdzonego na własne życie. Należy za-

33 Ibidem, s. 433.

34 Kodeks karny. Część szczegółowa. Tom II. Komentarz do art. 117-277..., s. $892-893$.

35 J. Kosińska, Prawnokarna problematyka stalkingu, „Prokuratura i Prawo” 2008, nr 10 , s. 36.

Nowa Kodyfikacja Prawa Karnego 46, 2017

(C) for this edition by CNS 
znaczyć, iż nierzadko zachowanie sprawcy przybiera różnorodne formy i cechuje się wysokim stopniem intensywności, co z kolei wiąże się z niemałym obciążeniem psychicznym ofiary. W rezultacie pokrzywdzony podejmie być może nieodwracalną decyzję o odebraniu sobie najcenniejszego dobra, jakim jest życie. Dlatego też możliwość pociągnięcia do odpowiedzialności karnej sprawcy uporczywego nękania, którego następstwem jest targnięcie się pokrzywdzonego na własne życie, nawet pomimo pewnych niedostatków normatywnych, braku spójności z unormowaniem sankcji karnej na gruncie art. $207 \S 3$ k.k. czy art. $352 \S 3$ k.k., wydaje się być słusznym rozwiązaniem.

\section{Attempt against one's life by the aggrieved as an aggravated type of stalking}

\section{Summary}

This article is devoted to the issue of criminal liability for the crime of attempt against one's life by the aggrieved as an aggravated type of stalking. It is related to validity of penalisation of this type of behaviour. It was pointed to interpretative doubts concerning appearances of a crime, as well as joining a discussion about bittiness within the scope of regularising the penal sanction.

Keywords: stalking, crime, aggrieved, attempt on one's life, harassment. 